\title{
ence \\ Microplastics in the New Zealand Environment
}

\author{
Nur Atifah Mazlan ${ }^{\dagger}$, Lilian Lin and Heon E. Park $* \mathbb{D}$
}

check for

updates

Citation: Mazlan, N.A.; Lin, L.; Park, H.E. Microplastics in the New

Zealand Environment. Processes 2022,

10, 265. https://doi.org/10.3390/

pr10020265

Academic Editor: Maximilian

Lackner

Received: 11 January 2022

Accepted: 26 January 2022

Published: 28 January 2022

Publisher's Note: MDPI stays neutral with regard to jurisdictional claims in published maps and institutional affiliations.

Copyright: (c) 2022 by the authors. Licensee MDPI, Basel, Switzerland. This article is an open access article distributed under the terms and conditions of the Creative Commons Attribution (CC BY) license (https:/ / creativecommons.org/licenses/by/ $4.0 /)$.

\author{
Department of Chemical and Process Engineering, University of Canterbury, Christchurch 8041, New Zealand; \\ nnuratifah@gmail.com (N.A.M.); 1li121@uclive.ac.nz (L.L.) \\ * Correspondence: heon.park@canterbury.ac.nz; Tel.: +64-3-369-0962 \\ † Current affiliation: Evyap Sabun (M) Sdn. Bhd., Pasir Gudang 81700, Johor, Malaysia.
}

\begin{abstract}
It is a concern that microplastics have been discovered in the food sources and water that we consume. This research was to evaluate the methods to isolate microplastics from organisms and how much of the environment of New Zealand (NZ), which is one of the least polluted countries, is contaminated by microplastics. New Zealand green-lipped mussels (Perna canaliculus) are considered to be an important product in the NZ food industry. For this reason, the existence of microplastics in these were investigated. Tarakihi fish (Nemadactylus macropterus) consume food near the bottom of ocean, so this fish can be an indicator of the contamination of microplastics denser than water. In addition, bottled water, tap water and sea salt samples were also investigated. To isolate solid particles in an animal body, its tissues were chemically digested. It was found that $10 \%(w / w)$ potassium hydroxide $(\mathrm{KOH})$ was a practical digestive protocol on biological tissues since polymers such as polyethylene terephthalate (PET), high-density polyethylene (HDPE), low-density polyethylene (LDPE), polypropylene (PP) and polystyrene (PS) are relatively resistant to $\mathrm{KOH}$. Thus, treating tissues with $\mathrm{KOH}$ can be considered a viable method to remove tissues and isolate microplastics. Nile red was used to stain the plastic particles from the samples for visual inspection. Fourier-transform infrared spectrometry (FTIR) was performed to identify the particles. It was evaluated that all those samples had traces of microplastics.
\end{abstract}

Keywords: microplastics; mussel; pollution; New Zealand environment; marine environment; tissue digestion; identifying plastic; polymer; NZ green-lipped mussel

\section{Introduction}

Plastic production increased exponentially since the 1950s to meet market demand and will exceed one billion tons by 2050 [1-3]. This intense production creates severe issues in the aquatic (such as freshwater or marine) environment. One specific issue is the development and accumulation of microplastics (MPs), which are defined as particles that are smaller than $5 \mathrm{~mm}$ with no lower bound in size [4,5]. There are two types of MPs [5]: one intentionally made to give certain functions in products such as personal care and the other degraded from larger products. The generation of these MPs from lost or discarded plastic products in our marine environment is influenced by a combination of various factors. The dominant causes would be UV radiation and mechanical abrasion, which accelerate physical degradation of synthetic polymers [6]. The size of MPs became smaller and smaller over decades to sizes similar to planktons, which are the main food source for small marine organisms. The distribution of MPs in the aquatic environment is dependent on the plastics' density, which would either allow them to float or sink in water [7]. Plastics in the ocean cause problems to marine life as they are sometimes mistaken as food [2]. Organisms consuming other organisms containing plastics can lead to blockage of their intestinal tracts or even death due to insufficient food uptake or harmful chemicals from plastics being ingested into their body [8].

Currently, the major concern of MPs is the contamination to our marine environment and seafood consumed by humans. In recent years, global researchers have reported 
that MPs have been taken by aquatic organisms [9-15], such as fish-eating birds, marine mammals, fish, mussels, sea cucumber, etc., and that it was found in sea salt [16-21], tap or drinking water [20,22-25] and bottled water [26-30]. It was also found that New Zealand is no longer a safe zone [31-33]. Microplastics can be associated with chemicals used during polymer manufacture or absorbed contaminants and toxic substances. Even though it is possible that some of those have already oozed out of the plastics to the environment, those that are still presenting MPs may lead to adverse effects to human health [34]. These effects can come from seafood consumption. There have been active and ongoing studies of MPs contamination, but there is no current evidence that the intake of MPs can cause a negative effect to human health [35] although there has been research on whether the accumulation of MPs in gills of marine animals can affect their respiration rate [3]. Microplastics in the digestive tracts can migrate into other tissues [36-39], and live tissues of cells can be scanned using a CT scan to see the impact of leaching of MPs, but this is out of the scope of this project, and we did not study this aspect further.

New Zealand (NZ) is encompassed by the sea and ocean, which means that there are higher chances of the human population to be ingesting MPs through marine food with low chances of biodegradation [9]. For this reason, NZ has been chosen as the environment to identifying and quantifying MPs. Moreover, NZ has a relatively small population (more than 5 million) and is an isolated country. For example, Sydney, the closest and large overseas city, is more than $2000 \mathrm{~km}$ away from NZ. Thus, we can understand how significantly global MPs contamination has developed by studying the level of MP contamination in the NZ environment. As model environmental indicators, NZ water sources, tarakihi fish (deep sea perch, Nemadactylus macropterus) and NZ green-lipped mussels (Perna canaliculus) were studied. New Zealand's main water supplies comes from its lakes and rivers, which are connected to the main ocean. In addition, benthic and planktonic organisms can be found in these environments. Therefore, NZ bottled water, tap water and sea salt were also investigated to evaluate whether MPs exist in these resources. Sea salt has been known to be healthier than chemically synthesized salt because it is natural. However, if it is produced without filtering the sea water, it could contain particles in the sea water including MPs. By taking this into consideration, we have selected sea salt as an indicator of MP pollution [21]. Fish are commonly found in NZ, but the digestive system of fish is not typically consumed by humans. Thus, the probability of MPs being taken via fish consumption will be smaller. However, the presence of MPs in their digestive system may result in MPs migrating into other tissues [36-39]. Hence, the digestive tracts of fish were also chosen for studies. Mussels are commonly used as a water pollution biomarker [40] since they are able to tolerate and accumulate large concentrations of pollutants. In addition, they have high tolerance to temperature and salinity change [41]. In NZ, NZ green-lipped mussels are widely produced along the country's coastline and shore as it provides the most ideal environment for their growth. The gills of mussels are located internally, and function as an oxygen supplier. They collect food particles by utilizing its fine moving hairs (cilia) and mucus sheet to transport to their mouth. Mussel consumption by humans can create a pathway for MPs entering our human bodies because mussels are generally eaten as a whole, including their digestive tract. In addition, NZ green-lipped mussel oil can be extracted using supercritical fluids, which can lead to potential chemicals, if any, being extracted from MPs, and this will eventually end up in the final product. NZ green-lipped mussels are being suspended on lines in water during their farming, and thus, they live on food floating in the water, implying that they tend to intake floating MPs. Due to all these reasons, NZ green-lipped mussels were studied in this paper. Tarakihi fish are easily found in NZ shore, especially relatively shallow water. Thus, it can be a representative fish species. They live on a variety of organisms, such as crustaceans, shellfish, and worms, which they take from the mud on the bottom of the ocean. This implies that they may intake MPs that have settled on the bottom of the ocean, and thus, tarakihi fish can indicate the number of MPs present on the bottom of ocean. Considering all these reasons, tarakihi fish were studied in this project. 
There are three remaining questions in regards to identifying and quantifying MPs in animal bodies or the environment in NZ. Firstly, how can we isolate MPs from samples such as biological tissues? In order to separate solid particles from biological tissues, researchers use chemical digestion methods, i.e., decomposing biological tissues, assuming that the methods do not alter plastics. We used two chemical digestion methods in this study. Secondly, how do we identify plastics found in the animals or environment? Researchers use spectroscopy such as Fourier-transform infrared spectroscopy (FTIR) to find fingerprints of functional groups on polymeric chains over a wide spectral range. The principles of this technique rely on the absorption or emission of the sample at a particular frequency in relation to its vibrational motion of molecules. FTIR spectra illustrate peaks that represent the transitions between quantized vibrational energy states. These correspond to a particular functional group. Aluminum oxide filters are often used in FTIR as the carrier material, which allows the MPs to be measured directly on the filter substrate [42]. Synthetic plastics found in the environment can be identified by matching the experimental values to the literature values. Hence, we used FTIR in this study. Thirdly, does the isolation/identification method alter MPs? It could be possible to only collect the contents in the digestive tracts and analyze them without tissues, but MPs can migrate to other tissues including intestine walls as mentioned above, which could contain other organisms. Thus, it would still be favorable to digest samples chemically to remove biological tissues and isolate MPs. However, we still need to ensure that such chemical digestion would not alter the plastics. Hence, we have studied how chemical digestion methods alter plastics and selected a method which has insignificant effects for MP isolation.

\section{Materials and Methods}

\subsection{Model Microplastics Sample Preparation}

To study the effect of digestion methods on the intactness or chemical resistance of plastics, samples from five different types of plastics were collected from items such as water bottles, spray bottles, films, lunchboxes and drinking cups, which were sourced locally. The samples collected were polyethylene terephthalate (PET), high-density polyethylene (HDPE), low-density polyethylene (LDPE), polypropylene (PP) and polystyrene (PS), respectively. Model MP samples were obtained through sanding them with 80-grit sandpaper. Thereafter, these powder particles were sieved with a $500 \mu \mathrm{m}$ sieve to obtain the size required, which is below $500 \mu \mathrm{m}$. Each of the plastic powder (i.e., model MP) samples were rinsed with deionized (DI) water and then oven-dried at temperature $(T)=50{ }^{\circ} \mathrm{C}$ for duration $(t)=2 \mathrm{~h} \mathrm{[43]} \mathrm{and,} \mathrm{subsequently,} \mathrm{stored} \mathrm{in} \mathrm{clean} \mathrm{glass} \mathrm{vials.}$

\subsection{Testing Model Microplastic Sample Resistance to Chemical Digestion Methods}

Two different chemical digestion methods were used to test the chemical resistance of each of the five types of plastics. The mass of each sample before and after applying each method were measured. Each type of powdered plastic samples was prepared in triplicates. The first method was applying $20 \mathrm{~mL}$ of $10 \%(w / w)$ potassium hydroxide $(\mathrm{KOH})(\operatorname{Sigma}$ Aldrich, Burlington, MA, USA, $\geq 99.0 \%$, ACS reagent grade) solution into five separate test tubes. One type of plastic was placed into each test tube containing the solution. Every test tube was swirled around to ensure that all samples were coated with the solution and then left at $T=20{ }^{\circ} \mathrm{C}$ for $t=24 \mathrm{~h}$. Similarly, the second method was prepared by combining $10 \mathrm{~mL}$ each of $0.27 \mathrm{M}$ potassium persulfate $\left(\mathrm{K}_{2} \mathrm{~S}_{2} \mathrm{O}_{8}\right)$ (Sigma Aldrich, Burlington, MA, USA, $90 \%$, reagent grade) and $0.24 \mathrm{M}$ sodium hydroxide $(\mathrm{NaOH})$ (Ajax Finechem, Sydney, NSW, Australia, 100\% purity, analytical reagent grade) in five separate test tubes to make up $20 \mathrm{~mL}$ of solution. Each type of the plastic samples was placed in five separate test tubes, swirled around, and then left in that solution for the same amount of time and temperature as the first method. Next, samples from each method were vacuum filtered individually using nylon membrane filters $(0.8 \mu \mathrm{m}$ pore size, $90 \mathrm{~mm}$ diameter, Sterlitech, Auburn, WA, USA) and DI water in a glass flask. For every sample filtered, a fresh new filter was used. 
The filters containing the samples were placed in labeled glass petri dishes then oven-dried

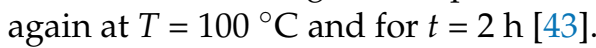

\subsection{NZ Green-Lipped Mussels and Tarakihi Fish Sample Preparation}

Raw NZ green-lipped mussels and tarakihi fish specimens were obtained from the local supermarkets as these will be the direct source of consumption for consumers. Specimens were stored in a freezer and removed from the freezer one hour prior to applying the chemical digestion methods. Each source was dissected to collect their digestive tracts, i.e., stomach and intestines. Figure 1 illustrates the digestive tracts retrieved from the NZ green-lipped mussel and tarakihi fish.

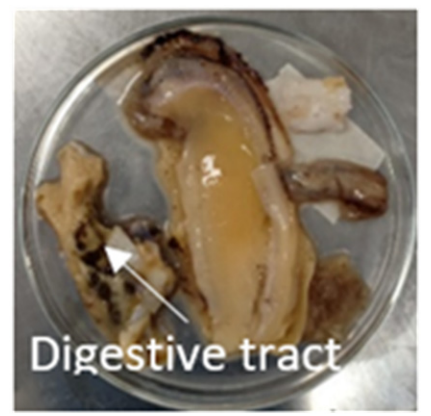

(a)

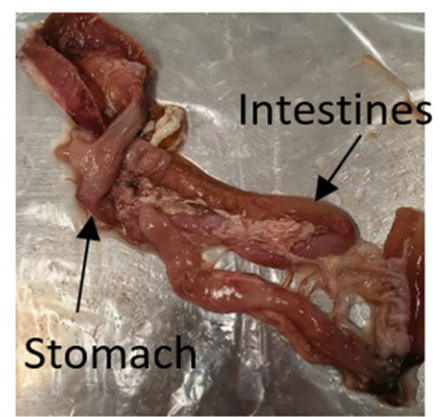

(b)

Figure 1. Digestive tracts from (a) NZ green-lipped mussel and (b) tarakihi fish, obtained at $T=$ room temperature.

Nine NZ green-lipped mussels were dissected to retrieve their digestive tracts, and the tissue-digestion method was implemented in triplicates. As for tarakihi fish, three of those were dissected to obtain their digestive tracts. Each type of biological sample was placed into separate conical flasks, and the first tissue-digestion method was applied, where $40-60 \mathrm{~mL}$ of $10 \%(w / w) \mathrm{KOH}$ ( $>3$ times the volume of digestive tracts) was added into each flask. These flasks were covered with aluminum foil and left at $T=20{ }^{\circ} \mathrm{C}$ for

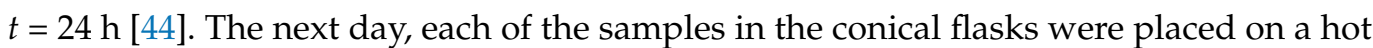
plate at $T=100{ }^{\circ} \mathrm{C}$ for $t=2 \mathrm{~h}$. Subsequently, DI water at $T=80^{\circ} \mathrm{C}$ was added into the flasks. The content in the flasks was swirled and immediately vacuum filtered with nylon membrane filters ( $0.8 \mu \mathrm{m}$ pore size, $90 \mathrm{~mm}$ diameter, Sterlitech, Auburn, WA, USA) and a glass filtration system. The nylon filters for every sample were constantly replaced when clogging occurred, and any sample remaining on the filter was carefully poured back into the flask. Before replacement, DI water was poured onto the filter to fully rinse any of the chemicals that may remain on the filter paper. Then, the filter paper was placed in a clean and labeled glass petri dish. Once pouring was finished, additional DI water at $T=80^{\circ} \mathrm{C}$ was poured into the flask and swirled around. This was then drained into the filtration system to ensure that all residues were fully retrieved.

After filtration, the filter papers containing the residues in clean and labeled glass petri dishes were oven dried at $T=50^{\circ} \mathrm{C}$ for $t=2 \mathrm{~h}$. After the drying process, these samples were stored for analysis. The analysis techniques implemented were optical visualization [45] and Fourier-transform infrared spectrometry (FTIR) [45].

\subsection{Nile Red Stock Solution Preparation}

Nile red stock solution with a concentration of $1 \mathrm{~g} / \mathrm{L}$ was produced in an amber glass container under a fume hood by adding Nile red (Sigma Aldrich, Burlington, MA, USA, $100 \%$ purity, microscopy grade) solids to acetone (ASCC, Auckland, New Zealand, 99.5\% purity, industrial grade) solution. This was then stored in a refrigerator at $T=4{ }^{\circ} \mathrm{C}$. The amount of stock solution produced was dependent on the frequency of this solution used to ensure it was sufficient to perform all experiments. 


\subsection{Water Samples Preparation}

Bottled water, tap water and sea salt water samples were prepared. Sea salt and $1.5 \mathrm{~L}$ bottled water were purchased from a local supermarket. Tap water of $5 \mathrm{~L}$ was retrieved from the laboratory at the University of Canterbury. This was obtained after removing the screen at the tip of the tap. Sea salt water was produced in the laboratory by dissolving $400 \mathrm{~g}$ of sea salt into $5 \mathrm{~L}$ of DI water to obtain a concentration of $8 \%(w / w)$ [20]. All these samples were poured in clean capped glass bottles, which were washed with DI water. For every $1 \mathrm{~L}$ of each water sample, $10 \mathrm{~mL}$ of $1 \mathrm{~g} / \mathrm{L}$ Nile red stock solution was added and mixed well. These samples were left sitting at $T=20{ }^{\circ} \mathrm{C}$ for at least $t=30 \mathrm{~min}$ [46]. Subsequently, all samples were rinsed and vacuum filtered individually using nylon membrane filters (0.8 $\mu \mathrm{m}$ pore size, $90 \mathrm{~mm}$ diameter, Sterlitech, Auburn, WA, USA). For every water sample, one filter paper was used for each sample. Each filter was stored in labeled and clean petri dishes separately until optical visualization and Fourier-transform infrared spectrometry (FTIR) analysis were implemented.

\subsection{Validation of Nile Red Staining}

There is a tendency that Nile red will stain biogenic materials such as lipids and chitins, which will result in an overestimation of the synthetic polymer in the samples collected. For this reason, each individual sample collected on filter paper were placed into a discrete and clean capped bottle where $20 \mathrm{~mL}$ of $3 \%$ hydrogen peroxide $\left(\mathrm{H}_{2} \mathrm{O}_{2}\right)$ (Ajax Finechem, Sydney, NSW, Australia, 35\%) was added into it. These samples were placed in an oven at $T=60{ }^{\circ} \mathrm{C}$ for $t=1 \mathrm{~h}$, thereafter at $T=100{ }^{\circ} \mathrm{C}$ for another $t=7 \mathrm{~h}$ [47]. The solution in each flask was filtered with new nylon membrane filters $(0.8 \mu \mathrm{m}$ pore size, $90 \mathrm{~mm}$ diameter, Sterlitech, Auburn, WA, USA). The filters were replaced constantly to minimize the effects of clogging. Additionally, the flask was rinsed with DI water to remove any content that would still be in the flask. The new filter paper containing the samples were stored in separate petri dishes until optical visualization and FTIR analysis were implemented.

\subsection{Optical Microscope Analysis}

A portion of Nile red stock solution was diluted using n-hexane solution (Ajax Finechem, Sydney, NSW, Australia, 99.5\% purity, laboratory grade) to obtain the desired concentration of $5 \mathrm{mg} / \mathrm{L}$. For every sample obtained in Sections 2.3 and 2.5, these were stained with $200 \mu \mathrm{L}$ of $5 \mathrm{mg}$ /L Nile red solution. Subsequently, every filter was washed with $100 \mu \mathrm{L}$ of $\mathrm{n}$-hexane and then air dried for approximately $t=5 \mathrm{~min}$ before examining them individually under a fluorescence coupled optical microscope (DMIL with Leica DFC490 camera, Leica, Wetzlar, Germany). Each filter was analyzed in non-fluorescent mode at $15 \times$ magnification to detect possible MPs. Any detected Nile red stained MPs were analyzed in fluorescent mode at optimal 120× magnification. In addition, for every particle identified in each type of sample, two parallel lines were drawn at the top and bottom of the particle image. The largest distance that incorporates the particle in between those two lines is the maximum Feret diameter, which is considered the mean size of the particle.

\subsection{Fourier-Transform Infrared Spectroscopy}

All samples were further analyzed using Fourier-transform infrared spectrometer (FTIR, Bruker ALPHA, Billerica, MA, USA) by comparing their spectral data with peak wavenumbers from literature [48-50]. The carrier material used was aluminum oxide filters, on which MPs were directly detected.

\subsection{Statistical Analysis}

Student $t$-test analysis was performed to reflect whether the mass change of MPs due to chemical digestion methods were statistically significant. A paired sample $t$-test with one tail and trusted $p$ value $<0.05$ was used and evaluated by Microsoft Excel Professional Plus 2019. 


\section{Results and Discussion}

\subsection{Size of Model Microplastic Samples}

The mean Feret diameter of model polyethylene terephthalate (PET) sample, i.e., the average size of the particles produced in Section 2.1 was selected and measured as a model. It was assumed that the obtained mean size of PET would be the same for the other model microplastic samples made by the same method in Section 2.1. Thus, it was assumed that the mean particle size for other plastic samples would be the same or close to the PET sample of $0.16 \pm 0.07 \mathrm{~mm}$. Figure 2 depicts the size distribution of PET particles.

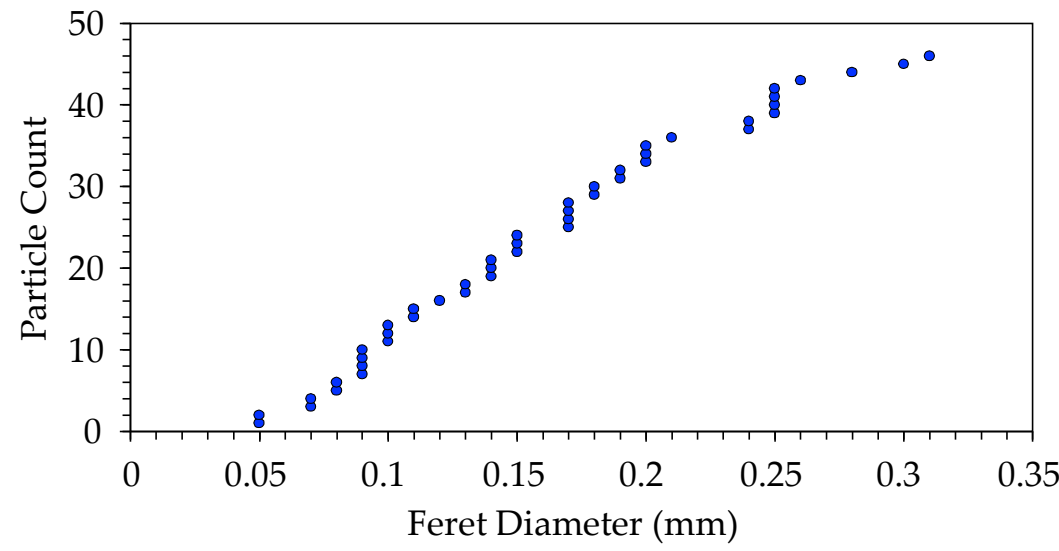

Figure 2. Particle Feret diameter and count of polyethylene terephthalate (PET). Mean Feret diameter of PET particles were found to be $0.16 \pm 0.07 \mathrm{~mm}$.

\subsection{Microplastic Mass Analysis before and after Chemical Treatment}

About $20 \mathrm{~g}$ of model MP particles was collected to make each sample. The mass of each sample before and after applying the chemical digestion methods was measured. Figures 3 and 4 illustrate the results for the first chemical digestion method, i.e., $10 \%(w / w)$ potassium hydroxide $(\mathrm{KOH})$ and second chemical digestion method, i.e., $0.27 \mathrm{M}$ potassium persulfate $\left(\mathrm{K}_{2} \mathrm{~S}_{2} \mathrm{O}_{8}\right)$ and $0.24 \mathrm{M}$ sodium hydroxide $(\mathrm{NaOH})$, respectively.

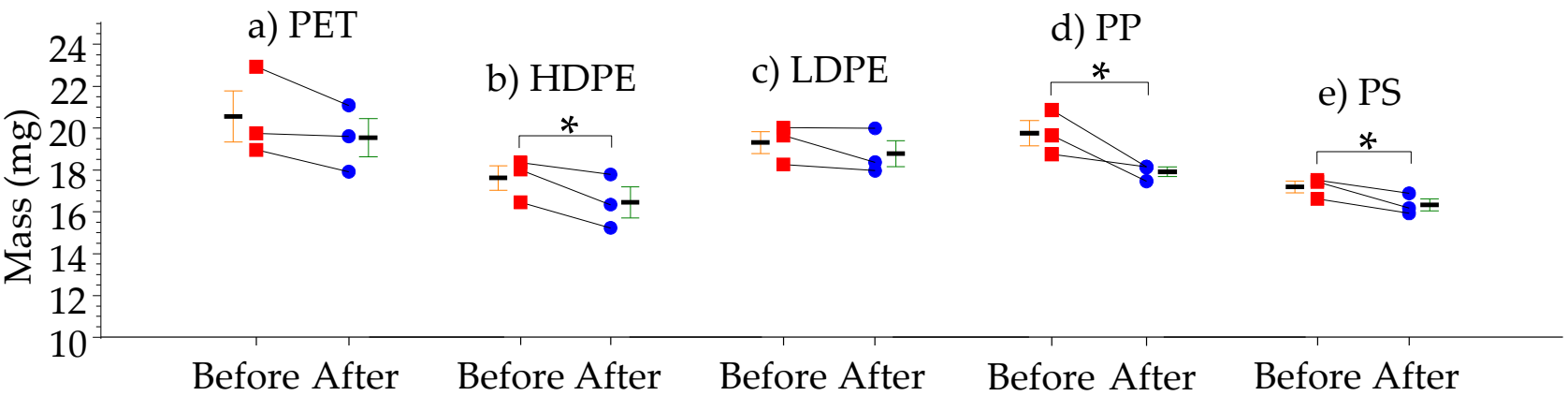

Figure 3. Mass change of five different types of model plastics and paired $t$-test analysis for each model microplastic sample of three repeats with $10 \%(w / w)$ potassium hydroxide $(\mathrm{KOH})$ solution at $\mathrm{V}=20 \mathrm{~mL}$ and $\mathrm{T}=20^{\circ} \mathrm{C}$ for $t=24 \mathrm{~h}$. The mean mass loss percentage (shown as short black bar) for (a) PET, (b) HDPE, (c) LDPE, (d) PP and (e) PS were 5.0, 6.7, 2.8, 9.3 and 5.0\%, respectively. Error bars are standard deviation \pm mean of experimental values. Solid points show the actual values of each datum, and the long thin black lines are the connection of the same samples before and after the treatment. ${ }^{*}=p<0.05$. 


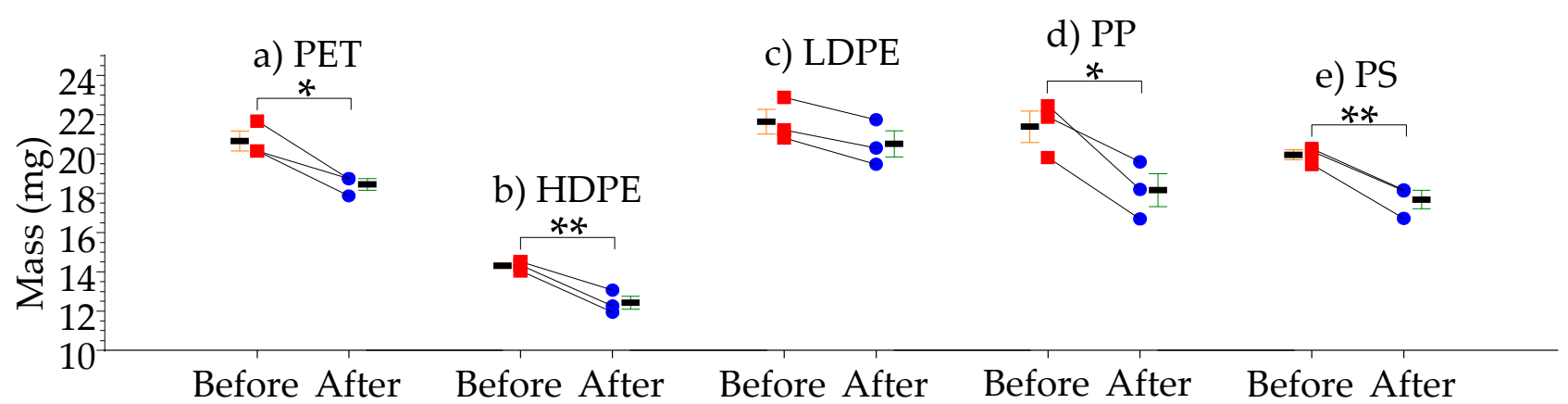

Figure 4. Mass change of five different types of model plastics and paired $t$-test analysis for each model microplastic sample of three repeats in $\mathrm{V}=10 \mathrm{~mL}$ with $0.27 \mathrm{M}$ potassium persulfate $\left(\mathrm{K}_{2} \mathrm{~S}_{2} \mathrm{O}_{8}\right)$ and $\mathrm{V}=10 \mathrm{~mL}$ of $0.24 \mathrm{M}$ sodium hydroxide $(\mathrm{NaOH})$ solution at $T=20^{\circ} \mathrm{C}$ for $t=24 \mathrm{~h}$. The mean mass loss percentage (shown as short black bar) for (a) PET, (b) HDPE, (c) LDPE, (d) PP and (e) PS were $10.7,13.2,5.2,15.1$ and $11.4 \%$, respectively. Error bars are standard deviation \pm mean of experimental values. Solid points show the actual values of each datum, and the long thin black lines are the connection of the same samples before and after the treatment. ${ }^{*}=p<0.05,{ }^{* *}=p<0.01$.

For the application of the first method shown in Figure 3, we can be $95 \%$ confident based on the statistical analysis $(p<0.05)$ that the mass of all the plastic types decreased after the treatment except for PET and LDPE. For the application of the second method illustrated in Figure 4, we can be 95\% confident that the mass of PET and PP decreased after the treatment. For HDPE and PS, we can be $99 \%$ confident based on the statistical analysis $(p<0.01)$. LDPE was found to be the most resistant to both chemical (base) treatments. This implies that LDPE is more stable than HDPE in such a basic environment. At a glance, this should have been the other way around considering the higher crystallinity in HDPE than LDPE and having very few tertiary carbons, which lead to fast thermal degradations. However, LDPE is also known for its good resistance to bases and acids and also shows less weight loss due to fungal isolates [51] implying resistant to chemical degradation. Thus, the result is not surprising even though the exact reason is not known.

The average mass loss was obtained to be 5.8 and $11 \%$ for the first and second method, respectively, i.e., the number of plastics in animal tissues will be less underestimated by the first method than the second method. In past research, the use of $\mathrm{KOH}$ is proven to be more useful in the studies of plastic ingestion by marine animals as well $[52,53]$. Moreover, there have been few studies on the use of $\mathrm{K}_{2} \mathrm{~S}_{2} \mathrm{O}_{8}$ and $\mathrm{NaOH}$. Hence, the first method was chosen to be applied to digest tarakihi fish and NZ green-lipped mussel tissues to isolate solid particles in this study.

\subsection{Optical Microscope}

The particles collected after the filtration process of NZ green-lipped mussel digestive tracts, tarakihi fish digestive tracts, sea salt water, tap water and bottled water were analyzed under an optical microscope first. This analysis was to investigate the potential MPs that were successfully stained with Nile red dye. Figure 5 shows three different shapes of solid particles stained by Nile red: fibers, fragments and beads, obtained from the samples under the optical microscope. Fibers are generally from fabric such as materials coming from laundry washing and fishing nets, while fragments are from broken down plastics. Beads are formed due to either plastics abrasion in the environment or from certain applications utilizing microbeads, such as toothpaste, cleansing scrubs, shower gel, etc. It is observed that the particles had a size range from $10-100 \mu \mathrm{m}$. 


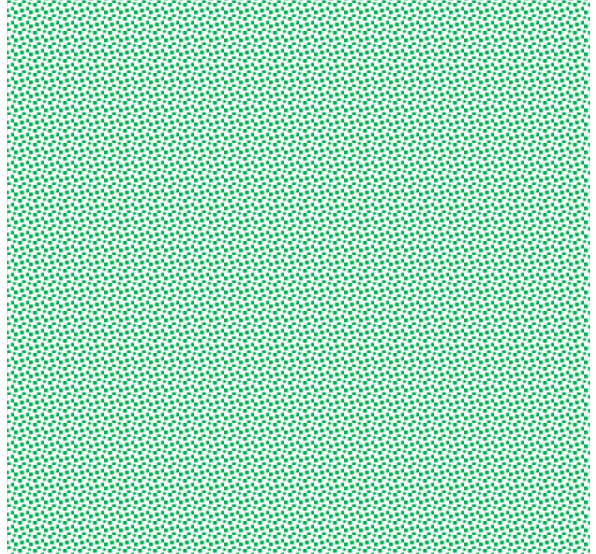

Figure 5. Images of fibers, fragments and bead particles under an optical microscope. The color of each particle has been removed for clarity purposes.

Figure 6 shows the number of particles found in every $100 \mathrm{~g}$ of raw NZ green-lipped mussel digestive tract and raw tarakihi fish digestive tract, as well as sea salt. In addition, it also expresses the number of particles per liter of tap water and bottled water. A relatively high number of fragments was found in the digestive tract of NZ green-lipped mussels and tarakihi fish. It is expected that some particles are solid fragments which originate from the food ingested by the animals. Few fibers were found in the NZ green-lipped mussel digestive tracts while many more fibers were found in the tarakihi fish digestive tracts. This is probably due to the different mouth sizes of tarakihi fish and NZ green-lipped mussels or the different types of food they intake. It is also possible that tarakihi fish, looking for food in the mud, are prone to take denser plastics, such as polyester fibers or fishing net fibers, than water. However, both NZ green-lipped mussel and tarakihi fish show a similar number of fragments, and this implies that a similar amount of microplastic fragments remain in their digestive tract with similar masses. Those particles were further analyzed using Fourier-transform infrared spectroscopy (FTIR) to verify their characteristics. Nile red only stains hydrophobic material; thus, the stained particles are either hydrophobic plastics or lipids.

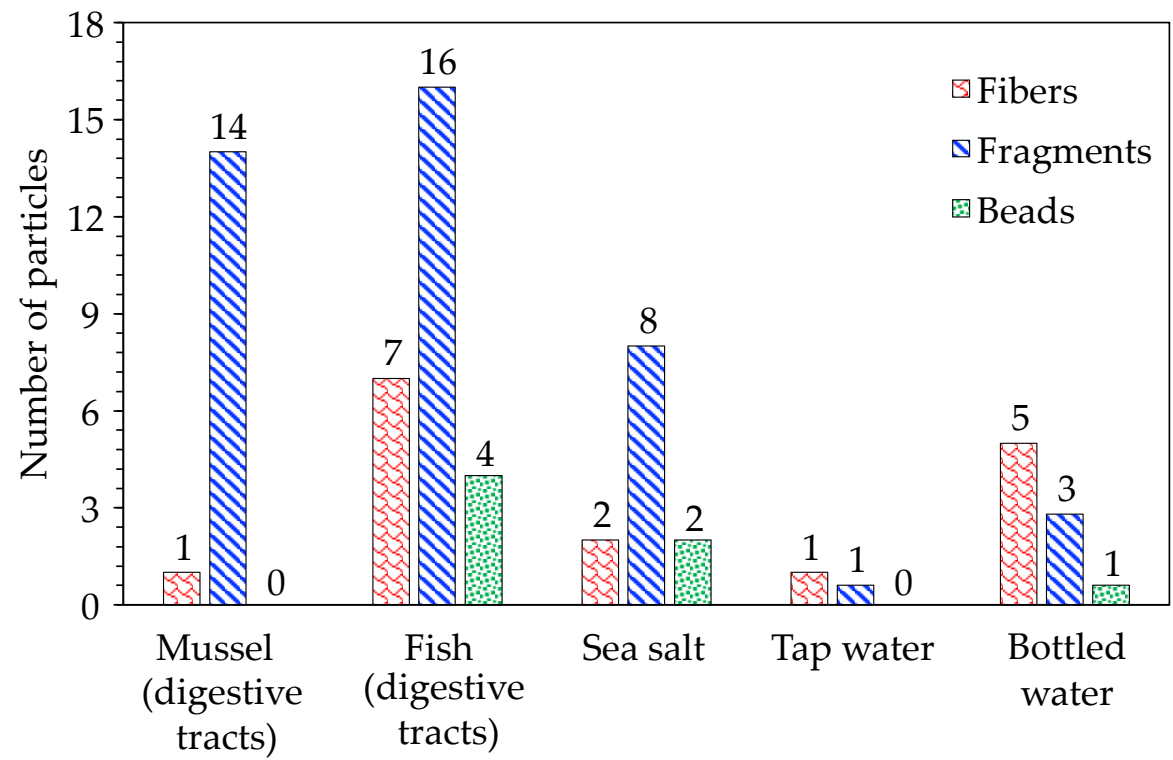

Figure 6. The number of particles found in each sample. Data attained express the normalized number of particles found per $100 \mathrm{~g}$ of NZ green-lipped mussel, tarakihi fish and sea salt samples. The normalized number of particles in tap water and bottled water samples are expressed per liter of sample. 


\subsection{MP Identification by Fourier-Transform Infrared Spectrometry (FTIR)}

The fragments and beads observed (i.e., stained by Nile red) under the optical microscope were then identified using FTIR. Fibers were not analyzed due to the small size of those. Those particles were classified by determining the apparent and distinct peak wavenumbers $[48,49]$. Figures $7-11$ show the attained spectra for the particles found in the samples. Figure 7, which shows particles found in NZ green-lipped mussels, and Figure 8, which shows particles found in sea salt, exhibit apparent peaks at around 1460 and $1375 \mathrm{~cm}^{-1}$, which are representations of $\mathrm{C}-\mathrm{H}$ scissoring and concentrations of methyl $\left(-\mathrm{CH}_{3}\right)$ groups, respectively $[48,49]$. Upon these peaks, they classify the presence of polypropylene (PP) in NZ green-lipped mussel digestive tract and sea salt samples. However, the peaks that occurred between 2500 and $2000 \mathrm{~cm}^{-1}$ in those two figures are different. This may be due to their different grades or degradations. Webb et al. [32,40] collected NZ green-lipped mussels around the NZ shore and observed apparent contamination by plastic fragments even though they did not identify them. Leung et al. [54] reported that green-lipped mussels caught near China are contaminated by plastic fragments as well. They used Raman microspectroscopy to identify those fragments, and more than half of the particles were identified as PP, about a quarter was PE and the rest was PS and PET. Our results are in accordance with their research in terms of PP fragments. There also were unidentified plastics in NZ green-lipped mussels in this study (Table 1), and those could be denatured PE, PS and PET or some other plastics. Kim et al. [21] analyzed MPs from sea salt around the world and found that there are various types of MPs and natural polymers including unidentifiable particles in the sea salt. They reported that the identified MPs composed one third each of PE, PP and PET. However, one of the three plastic particles in this study is also PP, while the other two were not identified. The density of PET is around $1.4 \mathrm{~g} / \mathrm{cm}^{3}$, so theoretically, such a plastic should sink quickly in the ocean before traveling far. However, the main sources of PET MP fragments are from water bottles, which normally float on the ocean surface, and thus, PET MPs are likely to be found worldwide. To minimize this type of MP source, we can consider replacing the use of that plastic with biodegradable polymers $[55,56]$. Even if biodegradable plastics degrade more slowly than anticipated, its degradation is still faster than non-degradable plastics.

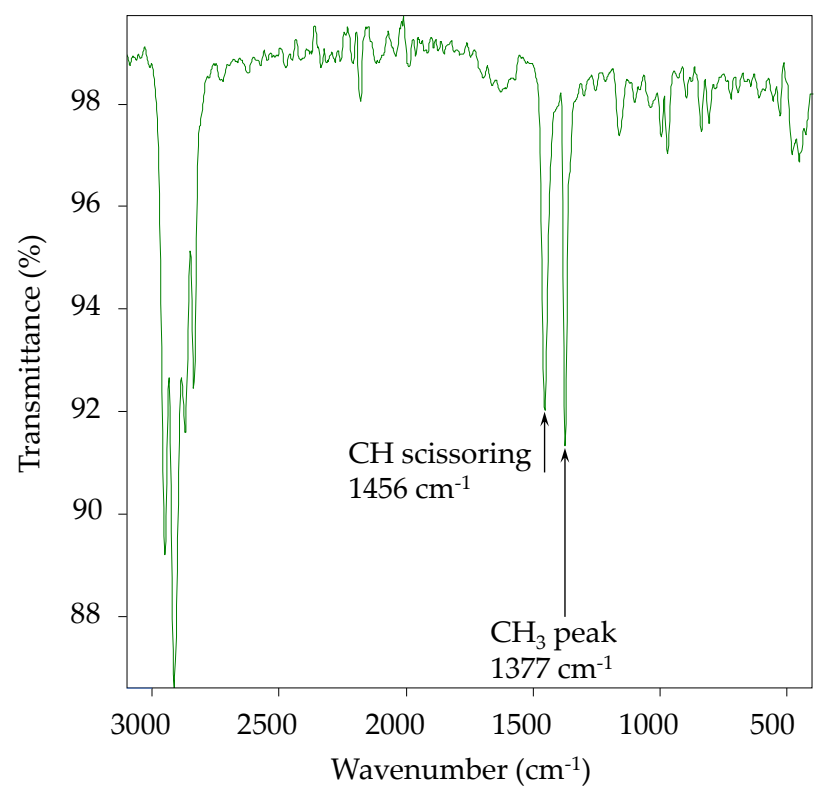

Figure 7. FTIR spectrum of a particle collected from the NZ green-lipped mussel digestive tract identified as PP. 


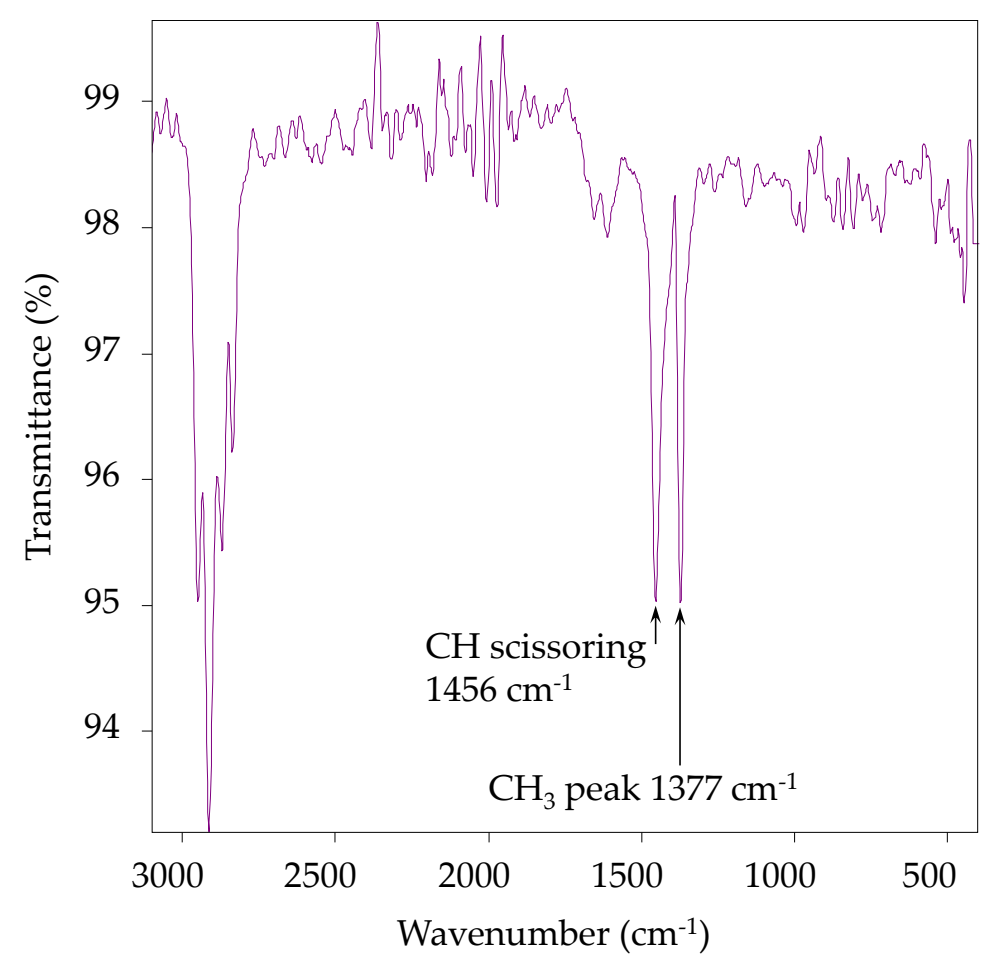

Figure 8. FTIR spectrum of a particle collected from sea salt identified as PP.

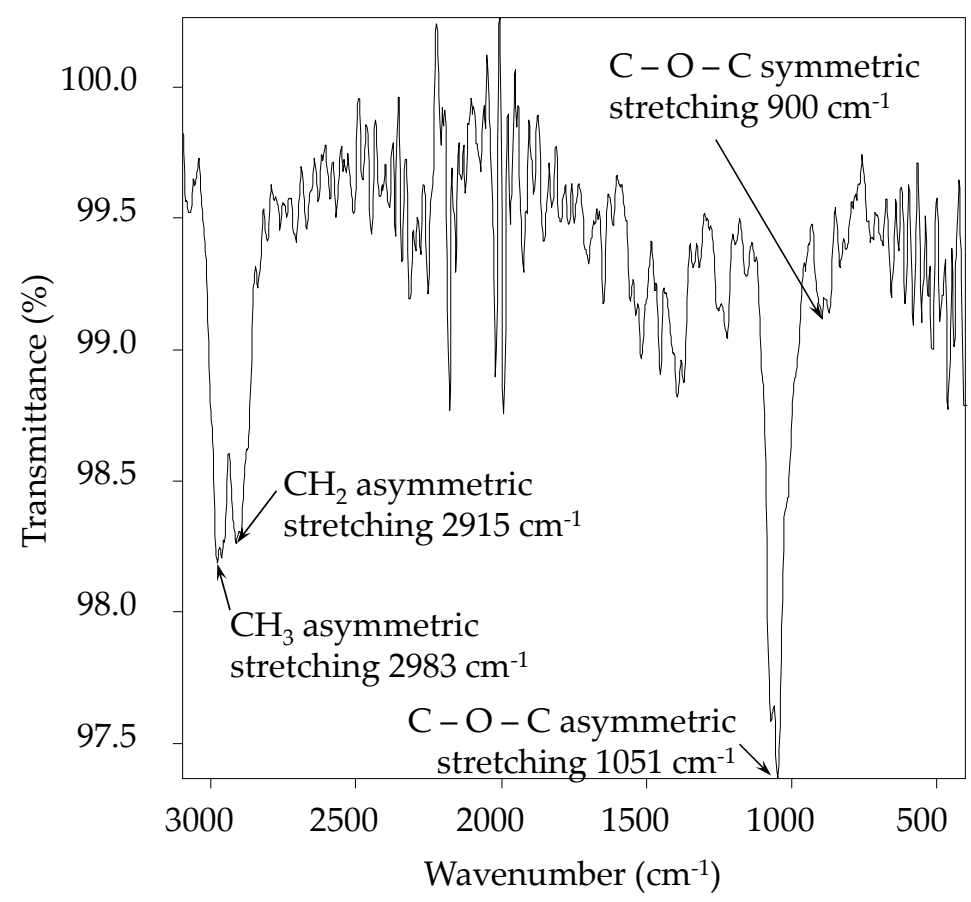

Figure 9. FTIR of a particle collected from the tarakihi fish digestive tract identified as polyethylene glycol. 


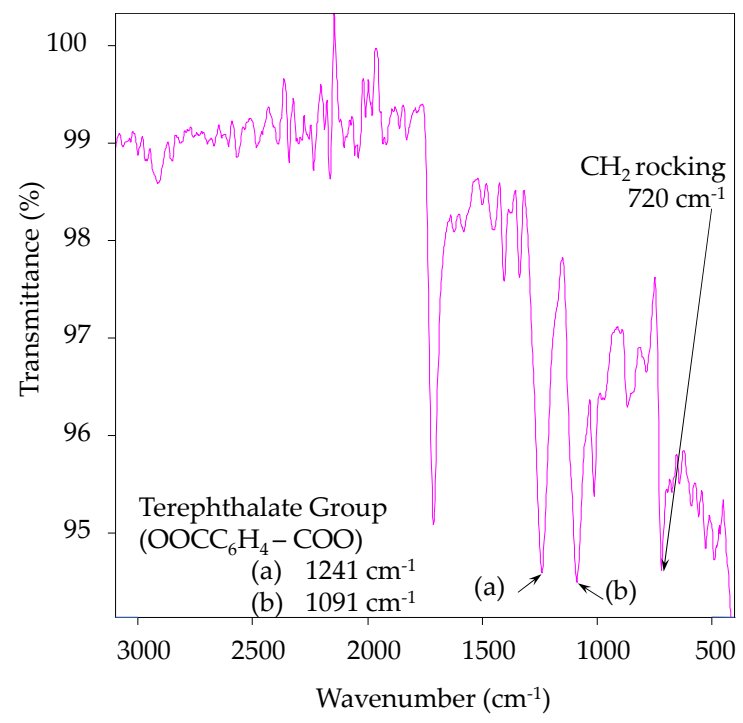

Figure 10. FTIR spectrum of a particle collected from tap water identified as polyester.

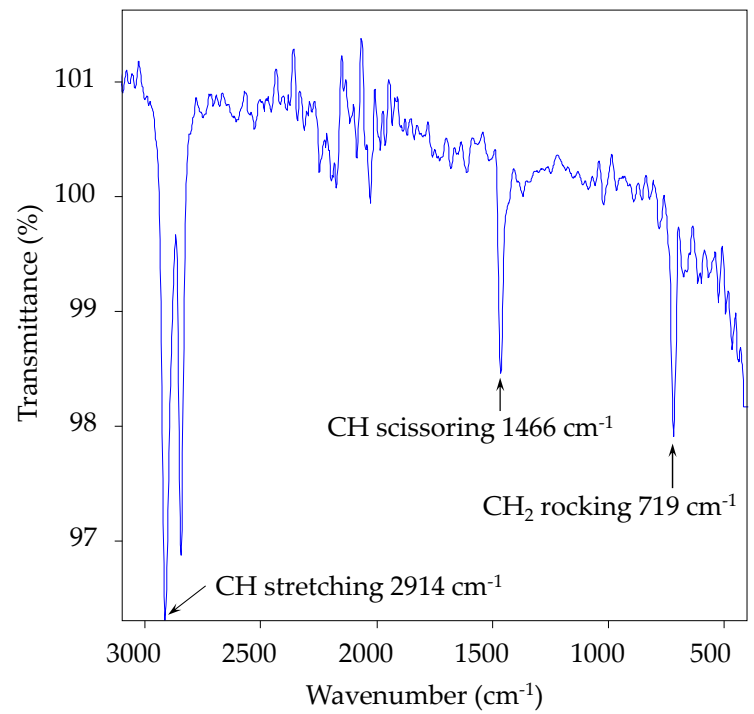

Figure 11. FTIR spectrum of a particle collected from bottled water identified as polyethylene.

Table 1. The number of particles (fragments and beads) found in each sample and identified plastics using FTIR. Particles found in NZ green-lipped mussels, tarakihi fish, and sea salt were normalized per $100 \mathrm{~g}$ of sample. Particles found in tap water and bottled water were normalized per liter of sample.

\begin{tabular}{|c|c|c|c|c|}
\hline \multirow[b]{2}{*}{ Type of Sample } & \multirow{2}{*}{$\begin{array}{c}\text { Total } \\
\text { Number of } \\
\text { Particles }\end{array}$} & \multirow[b]{2}{*}{ Not Polymer } & \multicolumn{2}{|c|}{ Showing Absorbance in $3000-500 \mathrm{~cm}^{-1}$} \\
\hline & & & $\begin{array}{c}\text { Unidentified } \\
\text { Polymer }\end{array}$ & Identified Plastic \\
\hline $\begin{array}{l}\text { NZ green-lipped } \\
\text { mussel digestive } \\
\text { tract }\end{array}$ & 14 & 9 & 3 & $2 \mathrm{PP}$ \\
\hline $\begin{array}{l}\text { Tarakihi fish } \\
\text { digestive tract }\end{array}$ & 20 & 10 & 9 & 1 polyethylene glycol \\
\hline Sea salt & 10 & 7 & 2 & $1 \mathrm{PP}$ \\
\hline Tap water & 1 & 0 & 0 & 1 polyester \\
\hline Bottled water & 4 & 0 & 0 & $3 \mathrm{PE}$ and $1 \mathrm{PP}$ \\
\hline
\end{tabular}


Figure 9 exhibits that asymmetric stretching of $\mathrm{CH}_{3}$ and $\mathrm{CH}_{2}$ groups, which normally appear around $2950-2970 \mathrm{~cm}^{-1}$ and $2920-2935 \mathrm{~cm}^{-1}$, respectively, is observed as a split peak at 2983 and $2915 \mathrm{~cm}^{-1}$. In addition, there were peaks at around $830-940 \mathrm{~cm}^{-1}$ and $1080-1150 \mathrm{~cm}^{-1}$, which suggest symmetric and asymmetric $\mathrm{C}-\mathrm{O}-\mathrm{C}$ stretching, respectively. By combining these peaks [49], they evaluate the presence of polyethylene glycol (PEG) in tarakihi fish digestive tracts. PEG particles can typically be found in skincare products, such as lotion, soaps, hair products and shower gel, which could easily be flushed into the environment with water after use. In addition, since the PEG density is $1.125 \mathrm{~g} / \mathrm{cm}^{3}$ (i.e., denser than ocean water) and considering that tarakihi fish consume food sources from the mud at the bottom of the ocean, it is coherent that PEG is found in them. Markic et al. [57] also reported that MPs were found in tarakihi fish caught near Auckland, New Zealand. However, they did not identify the plastics. Cverenkárová et al. [58] reported that in nearly all Australian fish, a piece of MP could be found, but PEG was not reported. PEG particles will normally settle on the bottom of the ocean relatively quickly, and this can explain why PEG is not always easily identified in studies. PEG on the bottom of the ocean will experience less degradation than floating plastics, and this can lead to prolonging MP issues. PEG found in tarakihi fish distinctly proclaims that animal habitat and their food consumption should be considered when animal models are selected for MP studies. This is because their food intake routes can govern the types of MPs found in them [59]. Due to NZ's remote location from highly populated counties [57], PEG contamination in tarakihi fish may imply that the MPs can be from domestic sources. Wootton et al. [60] expressed that the number and types of MPs found in fish in Australia and Fiji are very different even though the two countries are relatively close and are both located in the South Pacific Ocean. This implies that domestic sources of plastics are also important to control MPs. There can be a few approaches to minimize the sources of MPs, for example, intentional and unintentional disposal of plastics into the river or ocean should be prohibited. This means that personal and governmental recognition is necessary [31,33], researchers and engineers need to develop economical plastic recycling processes [55], and strong regulations should be enforced [31].

Although Figures 10 and 11 have representations of $\mathrm{CH}_{2}$ rocking, which is related to spatial configuration at around $720 \mathrm{~cm}^{-1}$, they have other apparent peaks that distinguish them. Figure 10 shows two apparent peaks next to each other at around 1240 and $1100 \mathrm{~cm}^{-1}$, which reflect the presence of terephthalate $\left(\mathrm{OOCC}_{6} \mathrm{H}_{4}-\mathrm{COO}\right)$ group $[49,50]$. Demonstrating the $\mathrm{CH}_{2}$ rocking and terephthalate nature shows that tap water contains polyester. It is not surprising to find polyester in tap water, as this is commonly used in packaging, fabrics and films. For example, polyester could easily originate from drained water of laundry washing, where tiny fabric pieces could have been spun off during the washing process and eluted from water filtering processes. It is likely that tap water from different location will show different MPs depending on the level of plastic use and its types [24]. Hence, different approaches are necessary to control MPs in tap water. For example, there can be a simple method to minimize MPs from laundry. Laundry washing water from washing machines should be filtered before releasing it down to drain to reduce the number of fibers and fragments discharged to the environment. Additionally, it is rather simple to minimize MPs in the tap water such by installing a water filtration system on the tap. However, nano-sized MPs could not be filtered by these methods. It has been evaluated that there are existing nanoparticles in tap water, but the presence of those does not seem to cause any major issues to human health under controlled exposure [35]. Those nanoparticles are out of the scope of this study; thus, no further investigation was performed.

Figure 11 demonstrates $\mathrm{CH}$ stretching and $\mathrm{CH}$ scissoring around 2950 and $1460 \mathrm{~cm}^{-1}$, respectively. Although PE and PP share similar peaks, there is no apparent presence of a $\mathrm{CH}_{3}$ group peak at around $1377 \mathrm{~cm}^{-1}$, which can be seen in Figures 7 and 8, in Figure 11, implying that the spectrum does not illustrate PP. Nonetheless, there is a peak around that range with very weak intensity, which may convey the presence of methyl groups at the end of the polymer chain. Upon these aspects, including the exhibition of $\mathrm{CH}_{2}$ rocking, we 
can conclude that bottled water contains traces of polyethylene (PE) $[48,49]$. However, it is difficult to determine whether PE is high density (HDPE) or low density (LDPE) due to its high similarities. Since this particle was found in bottled water, it is likely that it would be HDPE rather than LDPE, as HDPE is commonly used to produce bottle packaging. LDPE is normally used to produce plastic bags. Singh [28] manifested how MPs can be introduced into bottled water from PP caps, but the identified MPs in this study was not PP. The cause of how PE entered into the studied bottled water is unknown and beyond the scope of this research. There were four particles identified per liter of bottled water (Table 1); much fewer than what Wong et al. [27] reported: 100 particles per liter of bottled water were found in Malaysia. This implies that the number of MPs in bottled water can vary significantly with the location of water production facilities. Distinct locations would use different water sources and may even use different filtration systems. Likewise, the air quality at various locations can also vary. Overall, in order to minimize MPs in bottled water, the process should be well regulated, including air quality, while packing materials and the type of methods used are also crucial.

Not all of the collected solid particles were identified even though we only focused on polymers that illustrated apparent peaks between $3000-500 \mathrm{~cm}^{-1}$. Hence, those particles, which could not be identified via using polymer spectra handbooks, were all particularly distinct from the spectra shown in there. However, Table 1 summarizes the number of particles identified and unidentified in each sample. There are more non-polymeric particles than polymer particles in samples from the ocean, and processed water (tap and bottled) shows much fewer particles than in mussel, fish and sea salt samples. It is possible that the polyester particle was introduced during the sampling and handling processes of tap water, and PP in bottled water could originate from the bottle cap. However, it is not clear why PE particles were found in bottled water. There can possibly be at least two reasons why samples from the ocean show that there are many unidentifiable polymers. Firstly, there could be a wide range of plastics in the ocean and not every one of those may be covered in polymer spectra handbooks. Secondly, it is also possible that polymers in the ocean underwent both physical and chemical degradation over decades, which could lead to plastics being converted into unconventional ones. It is expected that various MPs would be found in tarakihi fish and green-lipped mussel. This is because tarakihi fish typically source food not only in the ocean but also around mud areas, and hence, there are higher chances that it could ingest various MPs. As for green-lipped mussels, which are commonly utilized as a water pollution marker, they tend to intake a great extent of floating particles, leading to either solid particle accumulation temporarily or permanently. On the whole, a constructive identification technique that identifies all of the polymeric particles should be developed and employed to eventually provide a more thorough idea regarding MP pollutions for systematically controlling MPs.

\section{Conclusions}

We have confirmed that $10 \%(w / w)$ potassium hydroxide $(\mathrm{KOH})$ was able to degrade biological tissues, yet had less impact on plastics compared to the mixture of $0.27 \mathrm{M}$ potassium persulfate $\left(\mathrm{K}_{2} \mathrm{~S}_{2} \mathrm{O}_{8}\right)$ and $0.24 \mathrm{M}$ sodium hydroxide $(\mathrm{NaOH})$. Hence, $10 \% \mathrm{KOH}$ is recommended to be used to isolate solid particles from animal tissues by chemically digesting the tissues and food consumed by the animals. Since $10 \% \mathrm{KOH}$ method does degrade a small amount of plastics (approximately by $6 \mathrm{wt} \%$ ), this underestimation of the mass of MPs in animals' digestive tracts should be accounted for.

Fourier-transform infrared spectroscopy (FTIR) was able to capture traces of polypropylene (PP) particles in NZ green-lipped mussels and sea salt, polyethylene (PE) glycol in tarakihi fish, PE in bottled water and polyester in tap water. This does not conclude that each sample contains only one type of plastics. There were other MPs in each sample that could not be identified by the application of FTIR. This could possibly be due to physical and chemical degradation of the MPs or because no standard reference peaks were available. Hence, other methods should also be developed and utilized to eventually identify MPs 
for systematically controlling MPs. PEG identification in tarakihi fish explicitly suggests that the animals' habitat and their food preferences should also be considered when animal models are selected as indicators of MP pollution.

New Zealand (NZ) has been known as one of the least polluted countries. However, NZ food sources, such as NZ green-lipped mussel and tarakihi fish, and NZ water resources were not microplastic-free. This implies that the MPs issue is globally significant as there are sources of plastics domestically and in overseas. To minimize the generation of MPs, intentional and unintentional disposal of plastics should be heavily prohibited or reduced. This will not only require personal and governmental acknowledgements, but also stronger global regulations to be in place. Additionally, researchers and engineers need to develop viable yet economical plastic recycling processes. Even though biodegradable plastics degrade in a slower manner than expected, it would still be worthwhile to utilize those rather than using plastics that are not degradable. Overall, microplastics is a worldwide and ongoing issue; thus, global mitigations should be taken promptly.

Author Contributions: Conceptualization, N.A.M. and H.E.P.; methodology, N.A.M. and H.E.P.; software, N.A.M. and L.L.; validation, N.A.M., L.L. and H.E.P.; formal analysis, N.A.M. and L.L.; investigation, N.A.M.; resources, N.A.M. and H.E.P.; data curation, N.A.M. and L.L.; writing-original draft preparation, N.A.M. and L.L.; writing—review and editing, L.L. and H.E.P.; visualization, L.L.; supervision, H.E.P.; project administration, H.E.P.; funding acquisition, H.E.P. All authors have read and agreed to the published version of the manuscript.

Funding: This research was funded (HEP320) by the Department of Chemical and Process Engineering at the University of Canterbury, New Zealand.

Institutional Review Board Statement: Not applicable.

Informed Consent Statement: Not applicable.

Data Availability Statement: The data that support the findings of this study are available within the article and up on request.

Acknowledgments: Authors thank Rayleen Fredericks, Michael Sandridge, Glenn Wilson and Garrick Thorn of the Department of Chemical and Process Engineering at the University of Canterbury for their support. N.A.M. thanks Matthew Polson of the Department of Physical and Chemical Sciences at the University of Canterbury for the use of the FTIR.

Conflicts of Interest: The authors declare no conflict of interest.

\section{References}

1. Andrady, A.L.; Neal, M.A. Applications and societal benefits of plastics. Philos. Trans. R. Soc. B Biol. Sci. 2009, 364, 1977-1984. [CrossRef] [PubMed]

2. Sutherland, W.J.; Clout, M.; Côté, I.M.; Daszak, P.; Depledge, M.H.; Fellman, L.; Fleishman, E.; Garthwaite, R.; Gibbons, D.W.; De Lurio, J.; et al. A horizon scan of global conservation issues for 2010. Trends Ecol. Evol. 2010, 25, 1-7. [CrossRef] [PubMed]

3. Wayman, C.; Niemann, H. The fate of plastic in the ocean environment-A minireview. Environ. Sci. Process. Impacts 2021, 23, 198-212. [CrossRef] [PubMed]

4. Arthur, C.; Baker, J.E.; Bamford, H.A. Proceedings of the International Research Workshop on the Occurrence, Effects and Fate of Microplastic Marine Debris. NOAA Marine Debris Division, Tacoma, WA, USA, 9-11 September 2008; p. 10.

5. Kershaw, P.J. Sources, Fate and Effects of Microplastics in the Marine Environment: A Global Assessment; GESAMP: London, UK, 2015; p. 96.

6. Andrady, A.L.; Pegram, J.E.; Searle, N.D. Wavelength sensitivity of enhanced photodegradable polyethylenes, ECO, and LDPE/MX. J. Appl. Polym. Sci. 1996, 62, 1457-1463. [CrossRef]

7. Hidalgo-Ruz, V.; Gutow, L.; Thompson, R.; Thiel, M. Microplastics in the Marine Environment: A Review of the Methods Used for Identification and Quantification. Environ. Sci. Technol. 2012, 46, 3060-3075. [CrossRef] [PubMed]

8. Besseling, E.; Wegner, A.; Foekema, E.M.; van den Heuvel-Greve, M.J.; Koelmans, A.A. Effects of Microplastic on Fitness and PCB Bioaccumulation by the Lugworm Arenicola marina (L.). Environ. Sci. Technol. 2013, 47, 593-600. [CrossRef]

9. Auta, H.S.; Emenike, C.U.; Fauziah, S.H. Distribution and importance of microplastics in the marine environment: A review of the sources, fate, effects, and potential solutions. Environ. Int. 2017, 102, 165-176. [CrossRef] [PubMed]

10. Wagner, M.; Lambert, S. Freshwater Microplastics: Emerging Environmental Contaminants? Springer Open: Cham, Switzerland, 2018. [CrossRef] 
11. Baztan, J.; Jorgensen, B.; Pahl, S.; Thompson, R.C.; Vanderlinden, J.P. MICRO 2016. Fate and Impact of Microplastics in Marine Ecosystems: From the Coastline to the Open Sea; Elservier: Amsterdam, The Netherlands, 2017.

12. Crawford, C.B.; Quinn, B. Microplastic Pollutants; Elsevier: Amsterdam, The Netherlands, 2017.

13. Zeng, E.Y. Microplastic Contamination in Aquatic Environments:An Emerging Matter of Environmental Urgency; Elsevier: Amsterdam, The Netherlands, 2018.

14. Constant, M.; Kerherve, P.; Sola, J.; Sanchez-Vidal, A.; Canals, M.; Heussner, S. Proceedings of the International Conference on Microplastic Pollution in the Mediterranean Sea, Capri, Italy, 26-29 September 2017.

15. Cocca, M.; Di Pace, E.; Errico, M.E.; Gentile, G.; Montarsolo, A.; Mossotti, R.; Avella, M. Proceedings of the 2nd International Conference on Microplastic Pollution in the Mediterranean Sea, Capri, Italy, 15-18 September 2019.

16. Yang, D.; Shi, H.; Li, L.; Li, J.; Jabeen, K.; Kolandhasamy, P. Microplastic Pollution in Table Salts from China. Environ. Sci. Technol. 2015, 49, 13622-13627. [CrossRef] [PubMed]

17. Gündoğdu, S. Contamination of table salts from Turkey with microplastics. Food Addit. Contam. Part A 2018, 35, 1006-1014. [CrossRef]

18. Iñiguez, M.E.; Conesa, J.A.; Fullana, A. Microplastics in Spanish Table Salt. Sci. Rep. 2017, 7, 8620. [CrossRef]

19. Karami, A.; Golieskardi, A.; Keong Choo, C.; Larat, V.; Galloway, T.S.; Salamatinia, B. The presence of microplastics in commercial salts from different countries. Sci. Rep. 2017, 7, 46173. [CrossRef] [PubMed]

20. Zhou, Z.; Kosuth, M.; Mason, S.A.; Wattenberg, E.V. Anthropogenic contamination of tap water, beer, and sea salt. PLoS ONE 2018, 13, e0194970. [CrossRef]

21. Kim, J.-S.; Lee, H.-J.; Kim, S.-K.; Kim, H.-J. Global Pattern of Microplastics (MPs) in Commercial Food-Grade Salts: Sea Salt as an Indicator of Seawater MP Pollution. Environ. Sci. Technol. 2018, 52, 12819-12828. [CrossRef] [PubMed]

22. Kirstein, I.V.; Gomiero, A.; Vollertsen, J. Microplastic pollution in drinking water. Curr. Opin. Toxicol. 2021, 28, 70-75. [CrossRef]

23. Tong, H.; Jiang, Q.; Hu, X.; Zhong, X. Occurrence and identification of microplastics in tap water from China. Chemosphere 2020, 252, 126493. [CrossRef]

24. Mukherjee, A.; Danopoulos, E.; Twiddy, M.; Rotchell, J.M. Microplastic contamination of drinking water: A systematic review. PLoS ONE 2020, 15, e0236838. [CrossRef]

25. Dalmau-Soler, J.; Ballesteros-Cano, R.; Ferrer, N.; Boleda, M.R.; Lacorte, S. Microplastics throughout a tap water supply network. Water Environ. J. 2021, 1-7. [CrossRef]

26. Scircle, A.; Cizdziel, J.V. Detecting and Quantifying Microplastics in Bottled Water using Fluorescence Microscopy: A New Experiment for Instrumental Analysis and Environmental Chemistry Courses. J. Chem. Educ. 2019, 97, 234-238. [CrossRef]

27. Wong, N.H.; Chai, C.S.; Bamgbade, J.A.; Ma, G.F.; Hii, G.W. Detection of Microplastics in Bottled Water. Mater. Sci. Forum 2021, 1030, 169-176. [CrossRef]

28. Singh, T. Generation of microplastics from the opening and closing of disposable plastic water bottles. J. Water Health 2021, 19, 488-498. [CrossRef]

29. Zhou, X.; Wang, J.; Li, H.; Zhang, H.; Hua, J.; Zhang, D.L. Microplastic pollution of bottled water in China. J. Water Process Eng. 2021, 40, 101884. [CrossRef]

30. Mason, S.A.; Welch, V.G.; Neratko, J. Synthetic Polymer Contamination in Bottled Water. Front. Chem. 2018, 6, 407. [CrossRef] [PubMed]

31. De Bhowmick, G.; Sarmah, A.K.; Dubey, B. Microplastics in the NZ environment: Current status and future directions. Case Stud. Chem. Environ. Eng. 2021, 3, 100076. [CrossRef]

32. Webb, S.; Ruffell, H.; Marsden, I.; Pantos, O.; Gaw, S. Microplastics in the New Zealand green lipped mussel Perna canaliculus Mar. Pollut. Bull. 2019, 149, 110641. [CrossRef]

33. Pantos, O.; Peter, C.; Nicolas, J. Risk Profile: Microplastics in the Diet; FW18032; Mistry for Primary Industries: Welington, New Zealand, 2019.

34. Smith, M.; Love, D.C.; Rochman, C.M.; Neff, R.A. Microplastics in Seafood and the Implications for Human Health. Curr. Environ. Health Rep. 2018, 5, 375-386. [CrossRef] [PubMed]

35. Seaton, A.; Tran, L.; Aitken, R.; Donaldson, K. Nanoparticles, human health hazard and regulation. J. R. Soc. Interface 2009, 7, S119-S129. [CrossRef]

36. Abbasi, S.; Soltani, N.; Keshavarzi, B.; Moore, F.; Turner, A.; Hassanaghaei, M. Microplastics in different tissues of fish and prawn from the Musa Estuary, Persian Gulf. Chemosphere 2018, 205, 80-87. [CrossRef]

37. Wright, S.L.; Kelly, F.J. Plastic and Human Health: A Micro Issue? Environ. Sci. Technol. 2017, 51, 6634-6647. [CrossRef]

38. Collard, F.; Gilbert, B.; Compère, P.; Eppe, G.; Das, K.; Jauniaux, T.; Parmentier, E. Microplastics in livers of European anchovies (Engraulis encrasicolus, L.). Environ. Pollut. 2017, 229, 1000-1005. [CrossRef]

39. Atamanalp, M.; Köktürk, M.; Uçar, A.; Duyar, H.A.; Özdemir, S.; Parlak, V.; Esenbuğa, N.; Alak, G. Microplastics in Tissues (Brain, Gill, Muscle and Gastrointestinal) of Mullus barbatus and Alosa immaculata. Arch. Environ. Contam. Toxicol. 2021, 81, 460-469. [CrossRef]

40. Webb, S.; Gaw, S.; Marsden, I.D.; McRae, N.K. Biomarker responses in New Zealand green-lipped mussels Perna canaliculus exposed to microplastics and triclosan. Ecotoxicol. Environ. Saf. 2020, 201, 110871. [CrossRef] [PubMed]

41. Jovic, M.; Stankovic, A.; Slavkovic-Beskoski, L.; Tomic, I.; Degetto, S.; Stankovic, S. Mussels as a bio-indicator of the environmental quality of the coastal water of the Boka Kotorska bay (Montenegro). J. Serb. Chem. Soc. 2011, 76, 933-946. [CrossRef] 
42. Löder, M.G.J.; Kuczera, M.; Mintenig, S.; Lorenz, C.; Gerdts, G. Focal plane array detector-based micro-Fourier-transform infrared imaging for the analysis of microplastics in environmental samples. Environ. Chem. 2015, 12, 563-581. [CrossRef]

43. Dehaut, A.; Cassone, A.-L.; Frère, L.; Hermabessiere, L.; Himber, C.; Rinnert, E.; Rivière, G.; Lambert, C.; Soudant, P.; Huvet, A.; et al. Microplastics in seafood: Benchmark protocol for their extraction and characterization. Environ. Pollut. 2016, 215, 223-233. [CrossRef] [PubMed]

44. Zavridou, E.; Markantonis, K.; Argyrokastritis, I.; Voudouris, K.; Kallioras, A. Preliminary Results from Unsaturated Zone Studies in Unconfined Unconsolidated Coastal Aquifers. Proceedings 2018, 2, 642. [CrossRef]

45. Kershaw, P.J. Sources, Fate and Effects of Microplastics in the Marine Environment: Part Two of a Global Assessment; GESAMP No. 93; GESAMP: London, UK, 2016; p. 220.

46. Bach, C.; Dauchy, X.; Etienne, S. Characterization of poly(ethylene terephthalate) used in commercial bottled water. IOP Conf. Ser. Mater. Sci. Eng. 2009, 5, 012005. [CrossRef]

47. Erni-Cassola, G.; Gibson, M.I.; Thompson, R.C.; Christie-Oleza, J.A. Lost, but Found with Nile Red: A Novel Method for Detecting and Quantifying Small Microplastics (1 mm to $20 \mu \mathrm{m}$ ) in Environmental Samples. Environ. Sci. Technol. 2017, 51, 13641-13648. [CrossRef]

48. Mayo, D.W.; Miller, F.A.; Hannah, R.W. Course Notes on the Interpretation of Infrared and Raman Spectra; Wiley-Interscience: Hoboken, NJ, USA, 2004.

49. Kuptsov, A.; Zhizhin, G. Handbook of Fourier Transform Raman and Infrared Spectra of Polymers; Elsevier Science: Amsterdam, The Netherlands, 1998.

50. Pereira, A.P.D.S.; Silva, M.H.P.D.; Lima, É.P.; Paula, A.D.S.; Tommasini, F.J. Processing and Characterization of PET Composites Reinforced With Geopolymer Concrete Waste. Mater. Res. 2017, 20, 411-420. [CrossRef]

51. Ojha, N.; Pradhan, N.; Singh, S.; Barla, A.; Shrivastava, A.; Khatua, P.; Rai, V.; Bose, S. Evaluation of HDPE and LDPE degradation by fungus, implemented by statistical optimization. Sci. Rep. 2017, 7, 39515. [CrossRef]

52. Thiele, C.J.; Hudson, M.D.; Russell, A.E. Evaluation of existing methods to extract microplastics from bivalve tissue: Adapted $\mathrm{KOH}$ digestion protocol improves filtration at single-digit pore size. Mar. Pollut. Bull. 2019, 142, 384-393. [CrossRef]

53. Kühn, S.; van Werven, B.; van Oyen, A.; Meijboom, A.; Bravo Rebolledo, E.L.; van Franeker, J.A. The use of potassium hydroxide $(\mathrm{KOH})$ solution as a suitable approach to isolate plastics ingested by marine organisms. Mar. Pollut. Bull. 2017, 115, 86-90. [CrossRef] [PubMed]

54. Leung, M.M.-L.; Ho, Y.-W.; Maboloc, E.A.; Lee, C.-H.; Wang, Y.; Hu, M.; Cheung, S.-G.; Fang, J.K.-H. Determination of microplastics in the edible green-lipped mussel Perna viridis using an automated mapping technique of Raman microspectroscopy. J. Hazard. Mater. 2021, 420, 126541. [CrossRef] [PubMed]

55. Lin, L.; Lee, Y.; Park, H.E. Recycling and rheology of poly(lactic acid) (PLA) to make foams using supercritical fluid. Phys. Fluids 2021, 33, 067119. [CrossRef]

56. Gasek, N.; Park, H.E.; Uriarte, J.J.; Uhl, F.E.; Pouliot, R.A.; Riveron, A.; Moss, T.; Phillips, Z.; Louie, J.; Sharma, I.; et al. Development of alginate and gelatin-based pleural and tracheal sealants. Acta Biomater. 2021, 131, 222-235. [CrossRef]

57. Markic, A.; Niemand, C.; Bridson, J.H.; Mazouni-Gaertner, N.; Gaertner, J.-C.; Eriksen, M.; Bowen, M. Double trouble in the South Pacific subtropical gyre: Increased plastic ingestion by fish in the oceanic accumulation zone. Mar. Pollut. Bull. 2018, 136, 547-564. [CrossRef]

58. Cverenkárová, K.; Valachovičová, M.; Mackul'ak, T.; Žemlička, L.; Bírošová, L. Microplastics in the Food Chain. Life 2021, 11, 1349. [CrossRef]

59. Roch, S.; Friedrich, C.; Brinker, A. Uptake routes of microplastics in fishes: Practical and theoretical approaches to test existing theories. Sci. Rep. 2020, 10, 3896. [CrossRef]

60. Wootton, N.; Ferreira, M.; Reis-Santos, P.; Gillanders, B.M. A Comparison of Microplastic in Fish From Australia and Fiji. Front. Mar. Sci. 2021, 8, 690991. [CrossRef] 